\title{
Surface Preparation of (2024-T4) Aluminum Alloy by Electroless Plating
}

\author{
Nabaa S. Radhi \\ Metallurgy Department, College of Materials Engineering, University of Babylon/Babylon. Iraq. \\ dr.nabbaa@gmail.com \\ Baraa alkhaqani \\ Metallurgy Department, College of Materials Engineering, University of Babylon/Babylon. Iraq. \\ Baraaalkhaqani@gmail.com \\ \begin{tabular}{|l|l|l|} 
Submission date:- 8/4/2018 & Acceptance date:-20/6/2018 & Publication date:-27/9/2018 \\
\hline
\end{tabular}
}

\begin{abstract}
:
This study dealt with the process of coating (immersion) and the factors affecting this process stability of the solution and change the time and temperature of immersion. In this study, aluminum alloy (2024- $\left.\mathrm{T}_{4}\right)$ was applied with a solution consisting of zinc oxide and sodium hydroxide $(81 \mathrm{~g} / \mathrm{l} \mathrm{NaOH}+81 \mathrm{~g} / \mathrm{l}$ $\mathrm{ZnO}$ ). Thus, zinc sulphate formed by immersing the sample with nitric acid solution (50\% $\mathrm{HNO}_{3}+50 \%$ water). Then immersed in distilled water. The immersion process was carried out at a different temperature between $(25,55 \text { and } 65)^{\circ} \mathrm{C}$ and different time periods. The results showed an increase in the growth of the deposition layer with increasing duration of the sample and the electrical resistance of the samples and for the same periods. A correlation was drawn between time change and oxide layer growth. Curvature growth was shown with increasing time period for sample exposure to air. The correlation between electrical resistance and time period change was also determined. Simulation between the experimental results and theoretical calculated by using ANSYS version 15. Finally, to confirm the formation and growth of the oxide layer draw by using MATLAB version 15A, Topographic test was examined and XRD.
\end{abstract}

Keywords: Deposition layer, Electrical resistance, Curvature growth, ANSYS version 15 ,Topographic test and XRD.

\section{1- Introduction:}

The applications of metal membranes today cover important scientific and industrial fields because they have the competence to create surfaces that differ not only from the specifications of the base metals, but also from the specifications of the same materials manufactured by other technologies, thus gaining the qualities that make them more suitable for practical applications [1].

The problems of heating and energy consumption are a social and international issues specially in cars manufacturing because many association put a different clause and the most significant role for these clauses is to refinement the consumption of oil by reducing the car weight to reduce the fuel which consumption by these cars [2,3]. This action is more dependent on using lightweight materials such as aluminum alloys rather than heavy metals like steel. In spite of that, it is not easy to produce whole cars body from these materials for two reasons the cost and productivity. Therefore, the best solution for these problems are using cars structure consist of two materials or more such as using of steels and aluminum alloys [4].

On the other hands, the process of application two materials or more is not easy as thought, because for example (steel-aluminum) alloy has different metals joints and one of the these problems are removing of the oxide film that produced around the surface of both aluminum alloy and steel [1,3,4]. And the most effective way to remove the oxides film is applying coating methods on the metals joints and in Steelaluminum alloy zinc coating could be used and the oxide film will be removed by melting of zinc [4]. By the way, the melting of $\mathrm{Zn}$ alloys, the melting point of the binary alloy of (Al-Zn) and ternary alloy of (Al$\mathrm{Mg}-\mathrm{Zn}$ ) it is generally lower than the melting point of pure $\mathrm{Zn}$ [5]. For the previous reason, it could use low

Journal of University of Babylon for Engineering Sciences by University of Babylon is licensed under a Creative Commons Attribution 4.0 International License. 
temperature to achieve the bonding by using the binary alloy of (Al-Zn) and ternary alloy of $(\mathrm{Al}-\mathrm{Mg}-\mathrm{Zn})$ in coating due to lower melting temperature.

\section{Modeling}

The term of model has the conventional meaning of representation. A model is a nominal terms which produce to simulate and prophesy aspects of a system's behavior. The quickly mounting performance of computer devices "and computer's software has promoted the widespread usage of numerical simulation tools for the parts design and for the optimization of manufacturing processes. Modeling may be especially important in connection between coating and substrate materials, since the gradients often cause special problems"[6].

Figure (1 a) shows the samples of aluminum with layer of coating. While figure (1 b) shows meshing of these sample.

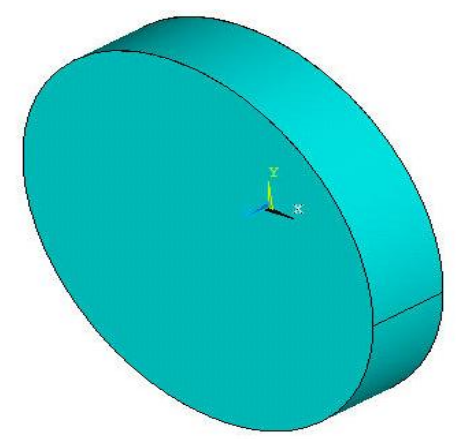

(a)

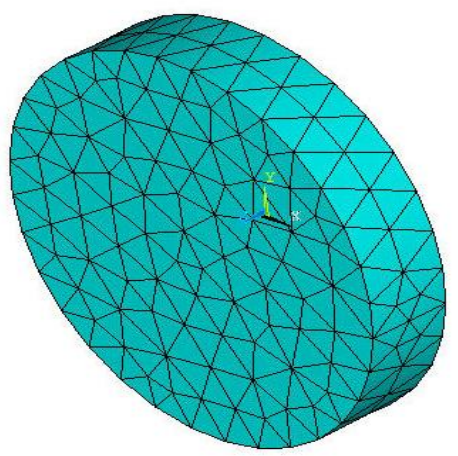

(b)

Figure (1) The samples of aluminum with layer of coating, (a) show drawing of the aluminum sample, (b) show meshing of the aluminum sample.

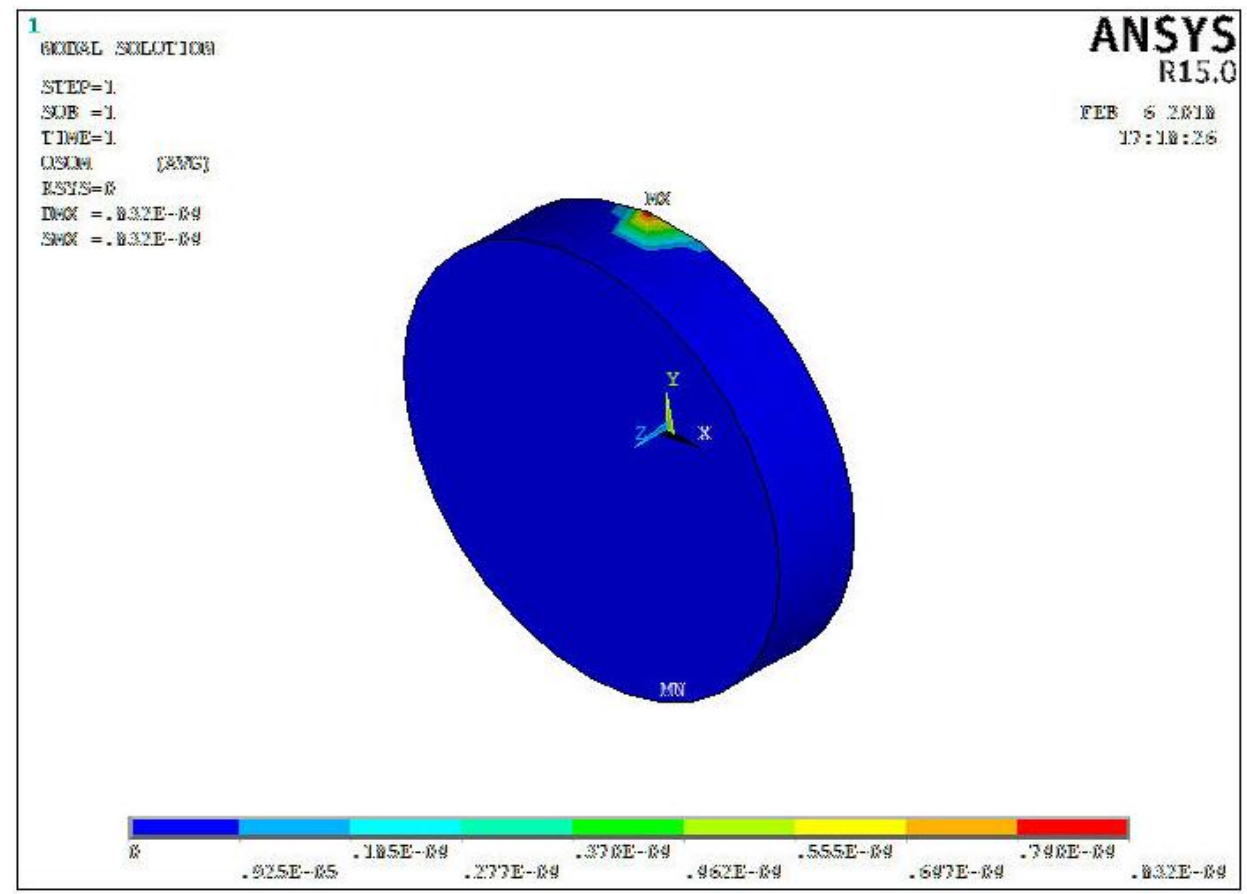

(a) Shows results of displacement at $1000 \mathrm{~N}$. 
Journal of University of Babylon for Engineering Sciences, Vol. (26), No. (8): 2018.

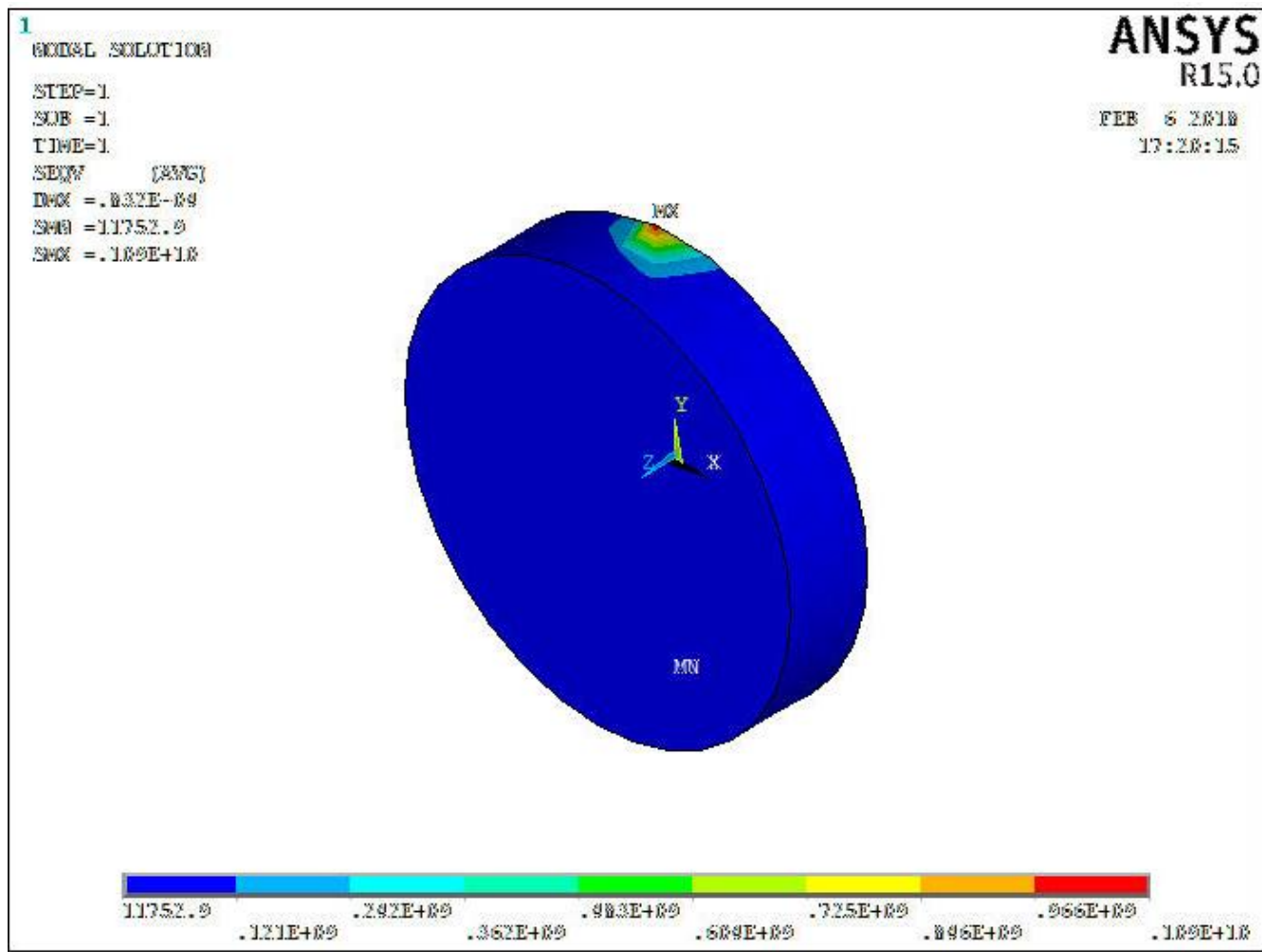

(b) Shows results of stress at $1000 \mathrm{~N}$.

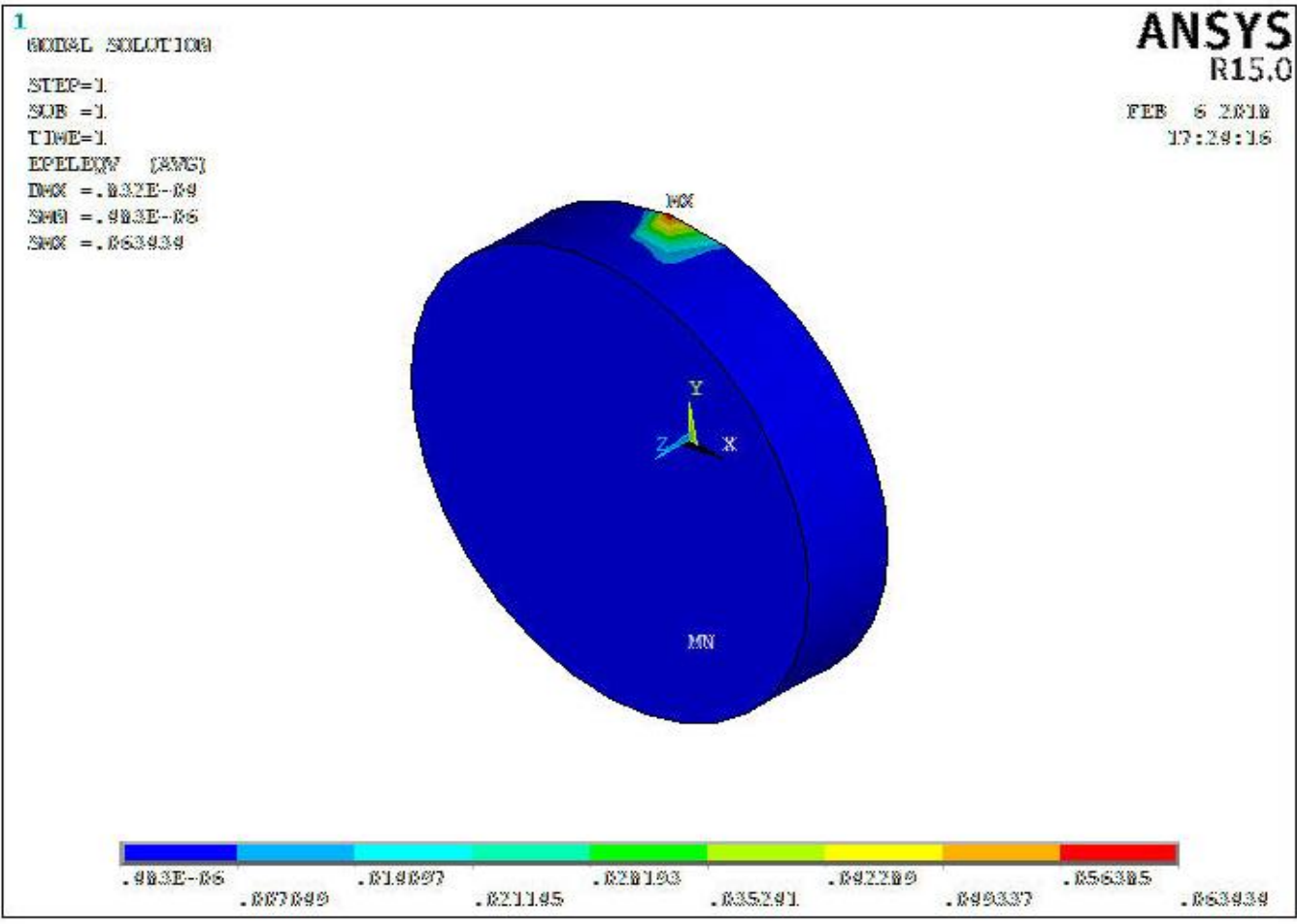

(c) Shows results of strain at $1000 \mathrm{~N}$.

Figure (2) shows results of displacement, stress and strain at $1000 \mathrm{~N}$. 


\section{Materials and Methods:}

\subsection{Al- alloy used in this work:}

The sample is required to be coated of aluminum alloy (2024-T4), the composition of alloy is tested by as shown in table (1).

Table (1) Chemical Composition (\%)

\begin{tabular}{|c|c|c|c|c|c|c|c|c|c|}
\hline Element & $\mathrm{Zn}$ & $\mathrm{Si}$ & $\mathrm{Fe}$ & $\mathrm{Cu}$ & $\mathrm{Mn}$ & $\mathrm{Cr}$ & $\mathrm{Mg}$ & $\mathrm{Ti}$ & $\mathrm{Al}$ \\
\hline Standard Value & $\mathbf{0 . 2 5}$ & $\mathbf{0 . 5}$ & $\mathbf{0 . 5}$ & $\mathbf{3 . 8}-4.9$ & $\mathbf{0 . 3 - 0 . 9}$ & $\mathbf{0 . 1}$ & $\mathbf{1 . 2 - 1 . 8}$ & $\mathbf{0 . 1 5}$ & balance \\
\hline Heat No.2015-570 & $\mathbf{0 . 0 3 7 5}$ & $\mathbf{0 . 0 8 0 4}$ & $\mathbf{0 . 2 7 4}$ & 4.1 & $\mathbf{0 . 4 8 2}$ & $\mathbf{0 . 0 0 6 9}$ & $\mathbf{1 . 5 9}$ & $\mathbf{0 . 0 1 8 5}$ & $\mathbf{9 3 . 4 1}$ \\
\hline
\end{tabular}

\subsection{Preparation of samples:}

In this paper, the samples were prepared with dimensions (diameter $25 \mathrm{~mm}$ and $5 \mathrm{~mm}$ in thickness). Preparation steps as shown in figure (3), first, grinding by silicon carbide paper with a softness (1000, 1200, 1400, and. 2000). The samples were then kept in cotton and silica, then imbedded in coated solution which contain from (zinc oxide solution with sodium hydroxide) $(81 \mathrm{~g} / 1$ zinc oxide $+81 \mathrm{~g} / \mathrm{l}$ sodium hydroxide)with $\mathrm{pH}=$ in different imbedded temperature $(25,55 \text { and } 65)^{\circ} \mathrm{C}$ and in different imbedded time $(5,15$ and 30)minute. The white color of the white aluminum sample was clearly colored to lead to the formation of zinc sulphate. They were dissolved in nitric acid (50\% acid-50\% water)with $\mathrm{pH}=$ for (1) minute and then treated with distilled water and alcohol finally these samples dried by hot air. The sample was ready to be weighed for the purpose of drawing the relationship between the time period and the growth of the oxide layer. The presence of zinc and its coverage of the aluminum sample makes the sample facilitate welding with other aluminum sample.

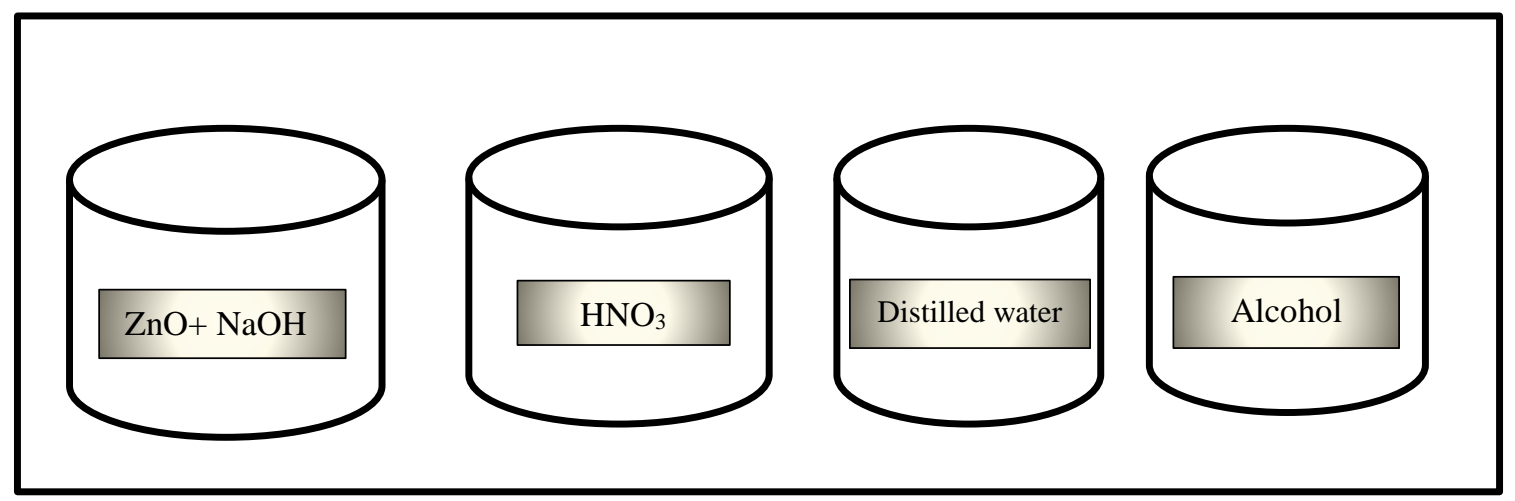

Figure (3) A diagram showing the treatment process for aluminum alloy.

After the immersion of the sample being dried and took the weight and continued to take the sample weight every half an hour and increase time it was found that the growth of the layer of oxide continues to increase until proven in five days, We also take the measurement of the electrical resistance of the sample at each time with the established temperature. Figure (4) illustrate the aluminum samples with and without coating. 

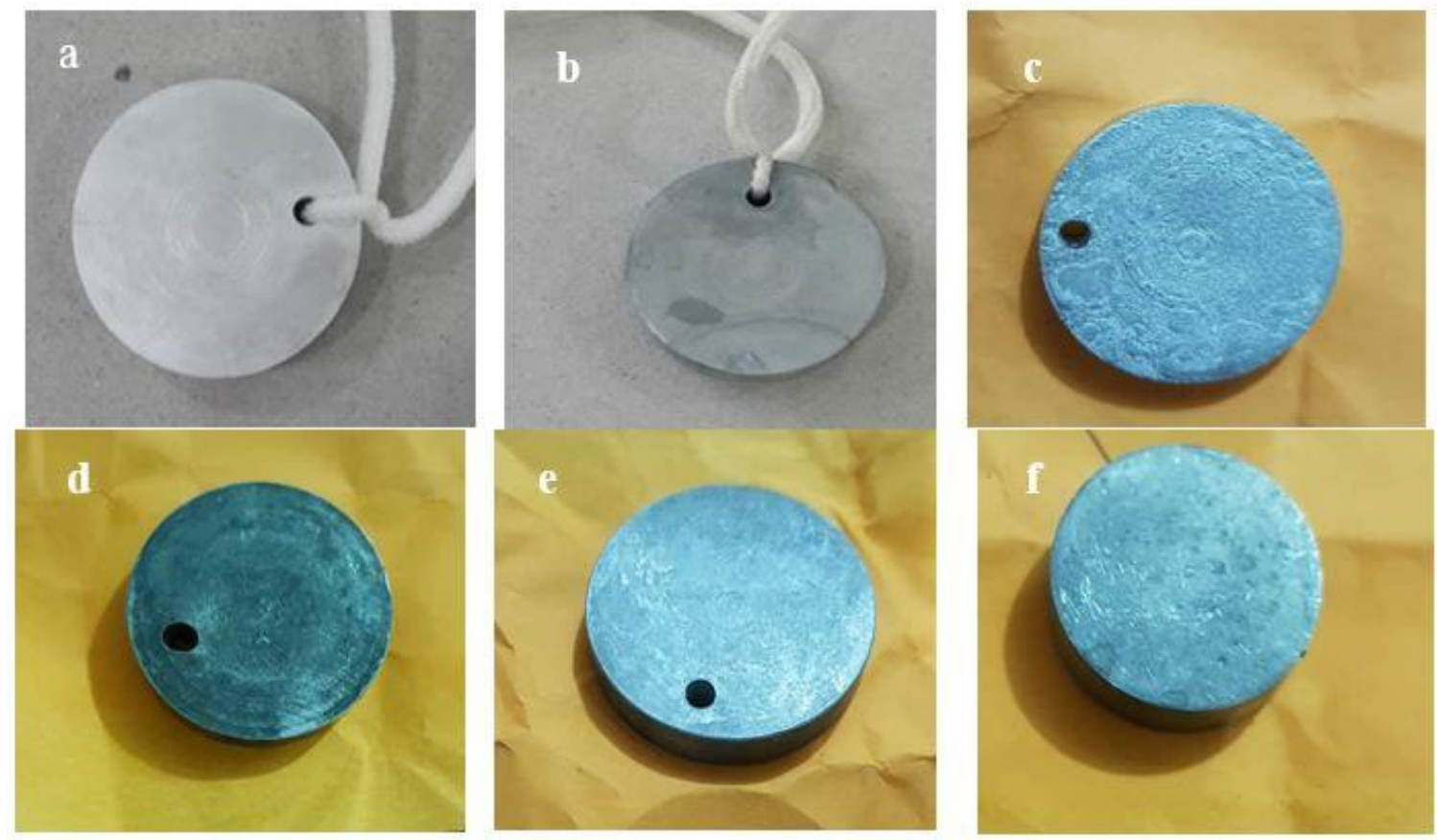

(a)Aluminum samples without coating.

(b)Aluminum samples with coating for 5 min.at $30^{\circ} \mathrm{C}$.

(c) Aluminum samples with coating for 10 min.at $30^{\circ} \mathrm{C}$.

(d) Aluminum samples with coating for 15 min.at $30^{\circ} \mathrm{C}$.

(e) Aluminum samples with coating for 30 min.at $55^{\circ} \mathrm{C}$.

(f) Aluminum samples with coating for 30 min.at $65^{\circ} \mathrm{C}$.

\section{Figure (4) show the aluminum samples with and without coating}

\subsection{X-Ray Diffraction test:}

Phase's analysis of prepared alloys is based upon X-ray diffraction technique. All X-ray diffraction tests are carried out at S.C. of Geological survey and Mining. Low angle X-ray diffraction is performed. Xray generator with $\mathrm{Cu} \mathrm{K \alpha}$ radiation at $40 \mathrm{~kW}$ and $20 \mathrm{~mA}$ is used. The target used in the $\mathrm{X}$-ray tube was $\mathrm{Cu}$, therefore $\lambda \mathrm{cu}=1.54060^{\circ} \mathrm{A}$ was used in obtaining the XRD patterns.

The X-ray is generated by general electric diffraction type Shimatzo (PW 1840) operating system at scanning speed of $5^{\circ}(2 \theta)$ per minute. The specimen has been held at a fixed angle of $\theta=5$ degrees relative to the case X-ray beam while the detector has motioned through an angle of 2(10-70) degrees.

\subsection{Light optical microscope}

The surface of prepared and coated samples are analyzed by an optical microscope attached with digital camera type (Tescan Vega III China made) in Babylon University/ Collage of Materials Engineering. The optical micrographs were at $(40 \mathrm{X})$ magnification.

\section{3- Results \& discussion}

\subsection{X-Ray Diffraction Patterns}

To improve the experimental fabrication of (Zinc coating) on Aluminum, $\mathrm{X}$-ray diffractions were made to ensure, that the fabricated $\mathrm{Zn}$ in each of $\mathrm{Al}$-samples were transformed homogeneously during the immersion practices. The diffraction patterns obtained from the tested samples, which the phases, as a 
result of coating, could be exposed. From these figures, the phase peaks are observed between $(2 \theta=40-50)$ degree as shown in figure (5)
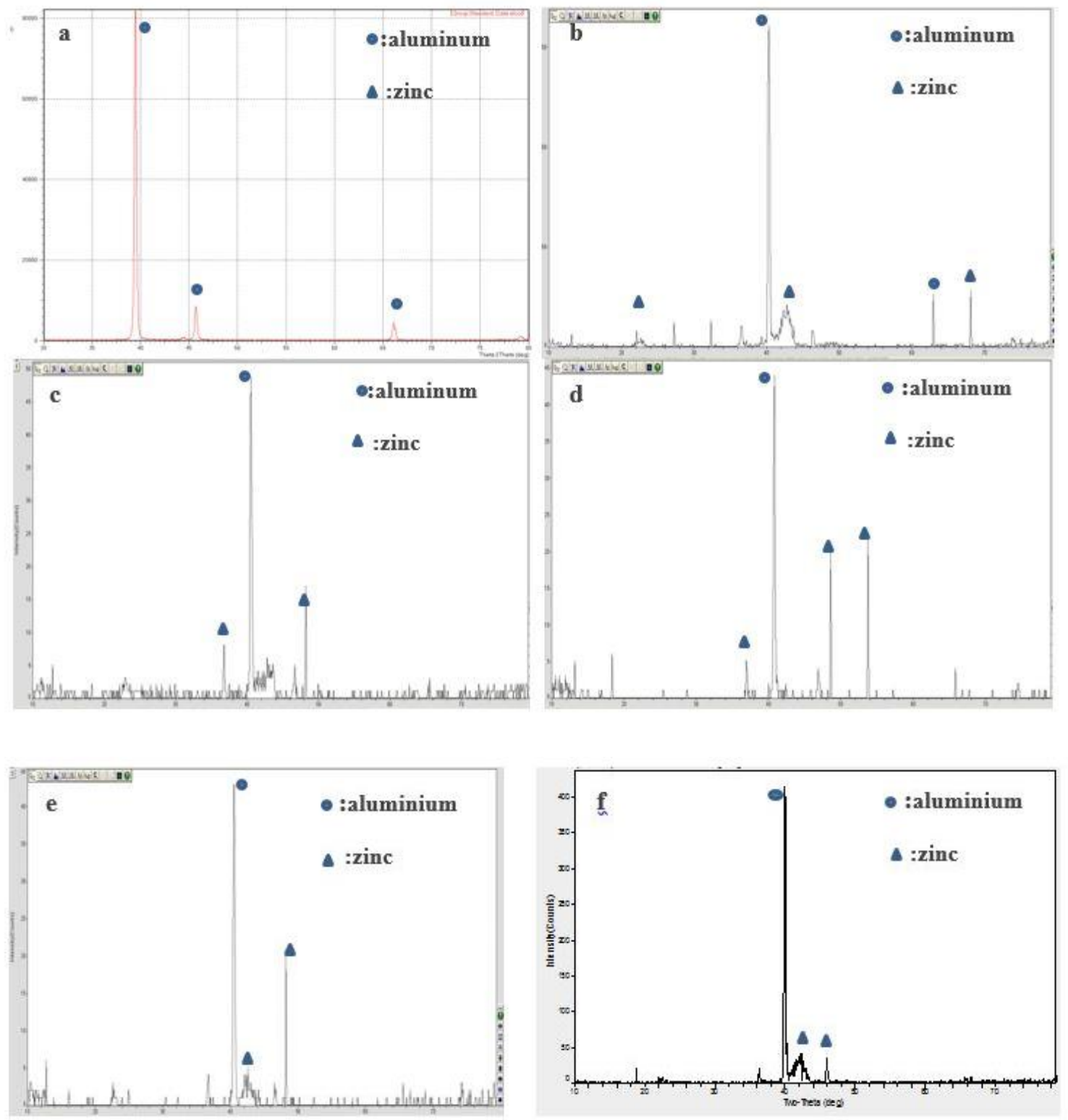

(a)Aluminum samples without coating.

(b)Aluminum samples with coating for 5 min.at $30^{\circ} \mathrm{C}$.

(c) Aluminum samples with coating for 10 min.at $30^{\circ} \mathrm{C}$.

(d) Aluminum samples with coating for 15 min.at $30^{\circ} \mathrm{C}$.

(e) Aluminum samples with coating for 30 min.at $55^{\circ} \mathrm{C}$.

(f) Aluminum samples with coating for 30 min.at $65^{\circ} \mathrm{C}$.

Figure (5) X-Ray diffraction of samples.

\subsection{Growth of the Oxide Layer:}

The weight of the sample was plotted with the time of exposure of the sample to the air for the purpose of knowing the speed of growth of the oxide layer on the surface of the sample where it was found 
that the oxide layer continues to increase until it reaches a constant weight then the surface is fully saturated and stable and appeared at half an hour and then an hour and then $\backslash$ an hour and a half found that The increase in the oxide layer is low. The weight of the sample is taken in days and the weight is taken Weight gain after a day found that the increase in the growth of the layer of oxide more and explained and continued to take weight after two days and so. We found that the growth of the layer of oxide become stable and stable when exposed to air for five days after it does interact with the air and size increased. The growth of the oxide layer is caused linearly at the time of the hourly text when the time in hours the oxide layer is homogeneous and contains pores that allow the air to pass through and continues to increase. As shown in figure (6) which is drawn by using MATLAB version $15 \mathrm{~A}$.

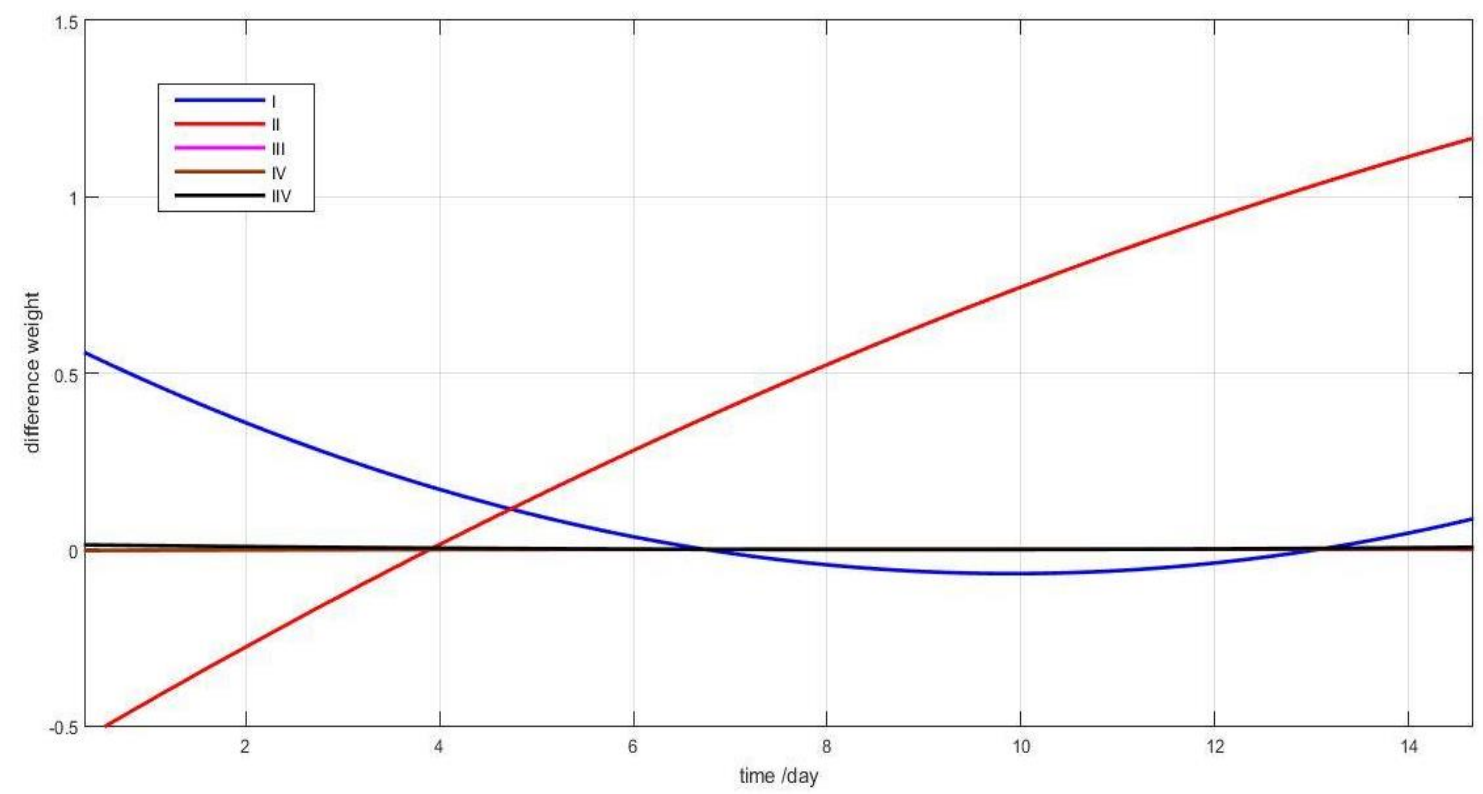

Figure (6) shows the growth of the oxide layer and the weight gain over time, draw by MATLAB.

Figure (6) shows that oxide film formation not mathematically linear with a time. This is due to the change in humidity and temperature without door test.

\subsection{Electrical Resistance:}

A relationship is drawn between the electrical resistances of the exposed sample to the air. Over time, the electrical resistance is increased by increasing the time in which the sample is subjected to air. The electrical resistance is increased by increasing the growth of the oxide layer. This is due to the fact that the oxide layer is a protective layer of electrical resistance is very high and is considered an electrical insulation and this leads to a significant increase in the electrical resistance of the sample coated. As shown in figure (7). Jaleel shows that the electrical resistance of growth film is a linear function of time up to 40 hours of film formation [10], [11].

Figure (6) is in a good agreement with figure (7) i.e both weight gained and resistivity of oxide film formation not linear with exposure time. 
Journal of University of Babylon for Engineering Sciences, Vol. (26), No. (8): 2018.

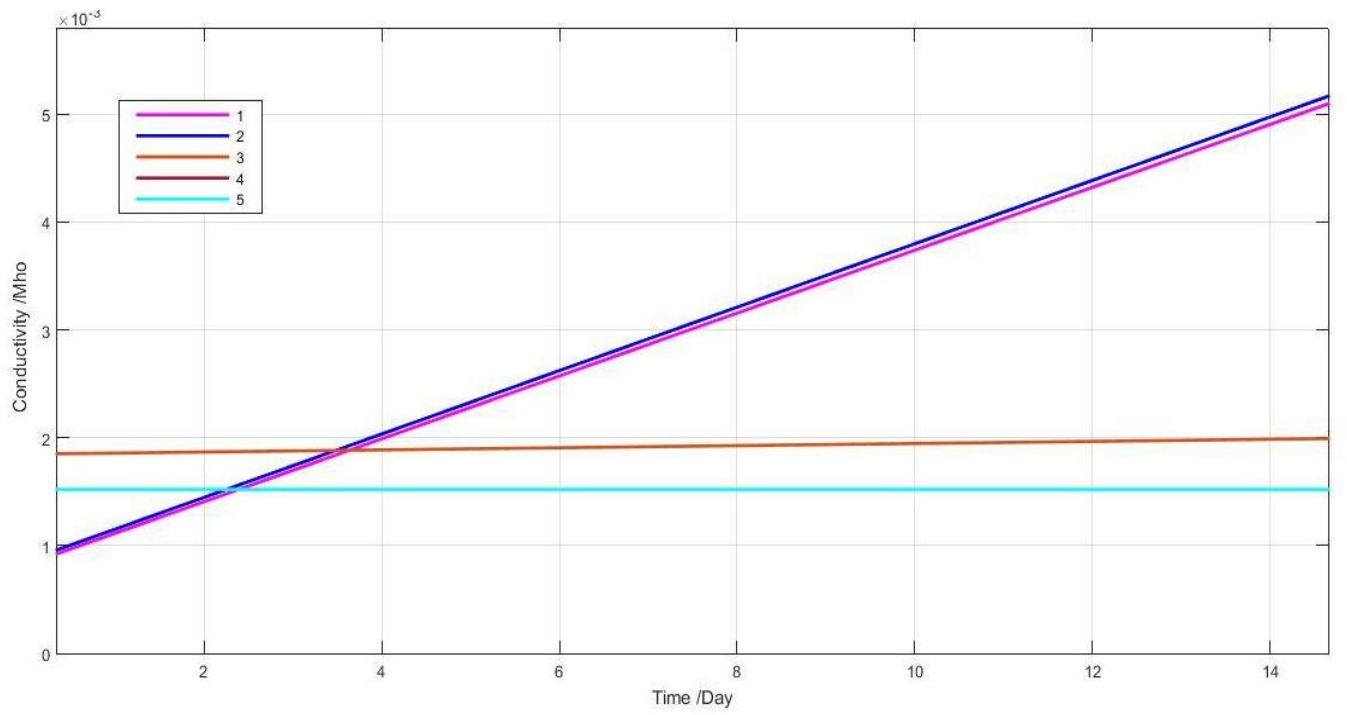

Figure (7) shows the electrical resistance of the oxide layer with time, draw by MATLAB.

\subsection{Topographic Test:}

This examination is done to see the formation of the coating layer clearly on the surface of the sample and cover the sample in full and it is important to see the disappearance of pores and lack of the surface of the sample as shown in the following form, which shows the sample before and after painting as shown in figure (8).

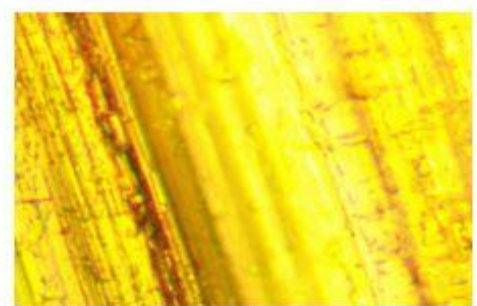

(a)

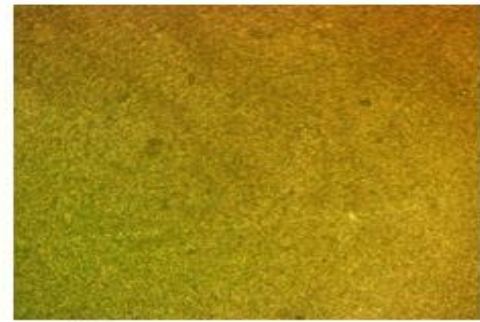

(d)

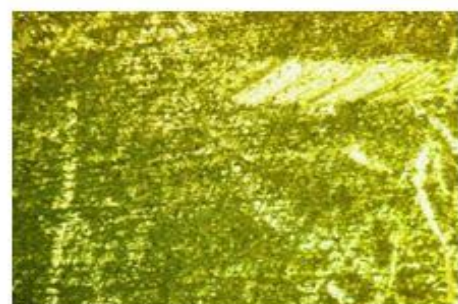

(b)

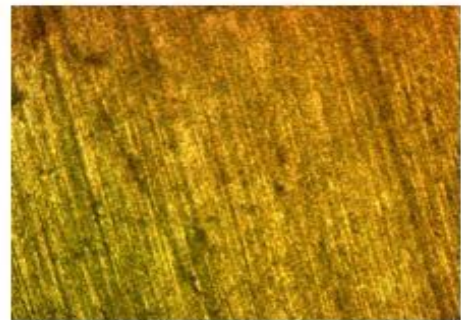

(e)

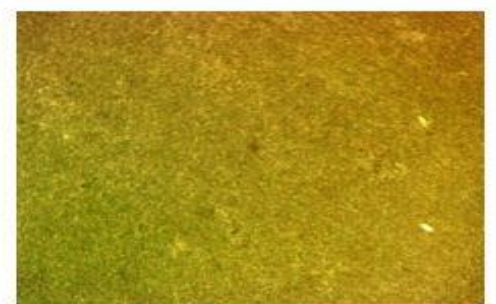

(c)

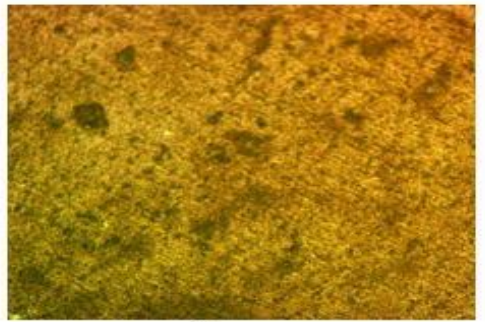

(f)

(a)Aluminum samples without coating.

(b)Aluminum samples with coating for 5 min.at $30^{\circ} \mathrm{C}$.

(c) Aluminum samples with coating for 10 min.at $30^{\circ} \mathrm{C}$.

(d) Aluminum samples with coating for 15 min.at $30^{\circ} \mathrm{C}$.

(e) Aluminum samples with coating for $30 \mathrm{~min}$. at $55^{\circ} \mathrm{C}$.

(f) Aluminum samples with coating for 30 min.at $65^{\circ} \mathrm{C}$.

Figure (8) shows the topographic of samples with and without coating. 


\section{Conclusion:}

Depending on the experimental results, the following deductions may be described:

1. The growth of the oxide layer continues to increase over time until it reaches saturation. The growth of the oxide layer stabilizes at a certain time and the weight is stabilized.

2. A clear increase in the electrical resistivity of the oxide layer over time. The increase in electrical resistance is confirmed when the oxide layer formed on the aluminum surface.

3. The samples whose coated $30 \mathrm{~min}$ in $55^{\circ} \mathrm{C}$ show best results in XRD, Topographic test, electrical resistivity and growth of oxide layer is caused linearly at the time and continues stable.

4. The simulation results of displacement at $1000 \mathrm{~N}$ is $6.23 \mathrm{e}-9$.

5. The simulation results of von mises stress at $1000 \mathrm{~N}$ is 11752.9 .

6. The simulation results of von mises strain at $1000 \mathrm{~N}$ is 0.63434 .

\section{CONFLICT OF INTERESTS.}

There are no conflicts of interest.

\section{References:}

[1] S.-I. Pyun and W.-J. Lee, Corros. Sci., 43, 353-363, 2001.

[2] A. Hirose: J. JSAE 61, 18-23, 2007.

[3] S. Sasabe: J. JSAE 61, 24-29, 2007.

[4] K. Miyamoto, S. Nakagawa, C. Sugi, H. Sakurai and A. Hirose: SAE Int.J. Mater. Manuf. 2 , 58-67, 2009.

[5] Y. Saito, H. Umeshita, T. Ogura and A. Hirose: Q. J. Jpn. Weld. Soc. 27, 187-191, 2009.

[6] FEM modeling:introduction

[7] T. Ogura, H. Umeshita, Y. Saito and A. Hirose: Q. J. Jpn. Weld. Soc. 27, 174-178, 2009.

[8] J. Y, Yan Cao (Corrosion Prevention by Applied Coatings on Aluminum Alloys in Corrosive Environments) Int. J. Electrochem. Sci., 10, 5222 - 5237, 2015.

[9] K. Ueda1;*2, T.Ogura1, Sh. Nishiuchi1;*3, K.Miyamoto2,T. Nanbu2 and Akio Hirose1 (Effects of ZnBased Alloys Coating on Mechanical Properties and Interfacial Microstructures of Steel/Aluminum Alloy Dissimilar Metals Joints Using Resistance Spot Welding*1) Materials Transactions, Vol. 52, No. 5, pp. 967 to 973 Special Issue on Aluminium Alloys 2010 \#2011 The Japan Institute of Light Metals, 2011.

[10] Dr. Jaleel Kareem Ahmed, preparation aluminum alloys to spot welding by using immersion coating, Journal of Karbala University, Vol.5 No.4 Scientific. December 2007.

[11] Sundus Abbas Jasim, Improving of some Mechanical properties, Microstructure and Electrical Conductivity of Pure Aluminum by adding Zinc, Journal of Babylon University/Engineering Sciences/ No.(1)/ Vol.(25): 2017. 
Journal of University of Babylon for Engineering Sciences, Vol. (26), No. (8): 2018.

\section{بأستخدام طريقة الطلاء اللاكهربائي (2024-T4)التهيئة السطحية لسبكة الالمنيوم

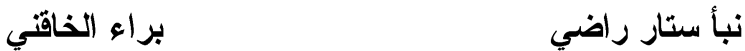 قسم الدعادن، كلية هندسة الدو واد، جامعة بابل / بابل. العراق.}

\section{Baraaalkhaqani@gmail.com $\quad \underline{\text { dr.nabbaa@gmail.com }}$}

تهدف الدراسة الحالية الى عملية تغطية (بالغمر البسيط)، ان العوامل المؤثرة على هذه العملية بثبوت المحلول وتغير درجة

الحرارة وزمن الغمر في الدراسة الحالية استخدمت سبيكة الالمنيوم من نوع (2024-T)

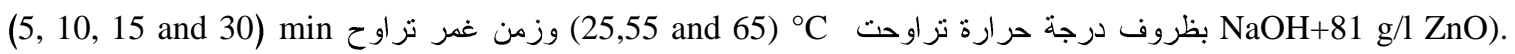
تخرج العينات حسب ظروف الترسيب من زمن ودرجة حرارة تغسل بالماء المقطر ثم تغمر في محلول مخفف من حامض النتريك 50 (50) \% HNO $\mathrm{HNO}_{3}+50 \%$ water )

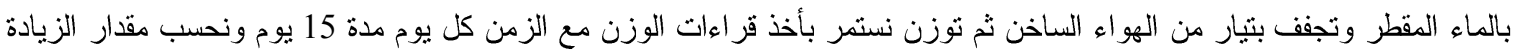

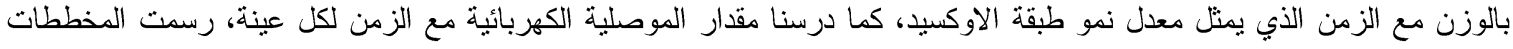

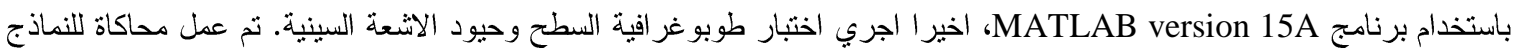
المطلية باستخدام برنامج 15 لدار استة السلوك الميكانيكي لطبقة الطلاء. الكلمات الادلة: الطبقة المنرسبة، المقاومة الكهربائية، معدل النمو، طوبو غر افية السطح وحيود الاشعة السينية. 